\title{
Variable Nutrient Environment Influence on Sweet Sorghum Stalk and Grain Yield
}

\author{
B. Balaji Naik ${ }^{1 *}$, S. R. Kumar ${ }^{2}$ and A. V. Ramanjaneyulu ${ }^{3}$
}

${ }^{1}$ Agricultural Research Station, (PJTSAU), Madhira, Khammam district, Telangana (507 203), India

${ }^{2}$ ICAR - Indian Institute of Millets Research, Rajendranagar, Hyderabad (500 030), India

${ }^{3}$ Regional Agricultural Research Station (PJTSAU), Palem, Nagarkurnool district, Telangana (509 215), India

\section{Corresponding Author}

B. Balaji Naik

e-mail: balajinaikbanoth789@gmail.com

\author{
Article History \\ Manuscript No. AR1733b \\ Received in $17^{\text {th }}$ November, 2016 \\ Received in revised form $30^{\text {th }}$ May, 2017 \\ Accepted in final form $4^{\text {th }}$ June, 2017
}

\begin{abstract}
Sweet sorghum is found to be one of the best sources for Ethanol production due to less irrigation requirement and cost of cultivation, at times Indian government had introduced the policy of blending ethanol with petrol and diesel. The present study was aimed to identify suitable sweet sorghum cultivar and quantify the influence of nitrogen and potassium on stalk and grain yield. The results indicated that a significant improvement in total and stripped stalk weight, juice yield, brix value and grain yields were observed with nitrogen fertilization @ $80 \mathrm{~kg} \mathrm{~N} \mathrm{ha}^{-1}$ alone $\left(\mathrm{N}_{1} \mathrm{~K}_{0}\right)$. The combined effect of $80 \mathrm{~kg} \mathrm{~N}$ and $40 \mathrm{~K}_{2} \mathrm{O}$ was found significant on total and stripped stalk weight in 2008 and juice yield in 2009. The cultivar SSV 84 produced higher mean grain yield of $4.01 \mathrm{t} \mathrm{ha}^{-1}$ in 2008 and PAC 52093 with $2.86 \mathrm{t} \mathrm{ha-1}$ in 2009 over $\mathrm{CSH} 22 \mathrm{SS}$. But this trend was reverse in terms of in total and stripped stalk weight and juice yields. The cultivar CSH $22 \mathrm{SS}$ recorded higher brix value (15.4) during drought year 2009 over its preceding wet year 2008. The highest net returns and B:C ratio were recorded with the conjunctive use of $\mathrm{N}$ and $\mathrm{K}_{2} \mathrm{O}$ at their recommended levels during both the years. The cultivars SSV 84 and PAC 52093 were found superior to $\mathrm{CSH} 22 \mathrm{SS}$ in terms of net returns and $\mathrm{B}: \mathrm{C}$ ratios during their respective years of study.
\end{abstract}

Keywords: Nutrient management, nitrogen, potassium and sweet sorghum

\section{Introduction}

United States, Brazil and the European Union contributes lion's share to biofuel production in the world. The production witnessed five times increase starting from 17 billion liters to 83.1 billion liters over a period of thirteen years since 2000 (WBA GBS report, 2014). Among the biofuels, ethanol and biodiesel are the two major ones. The feedstock that is being used to produce ethanol mainly includes sugarcane in Brazil, corn in the US and sugarbeet in the European Union (Huligol et al., 2004). Government of India had introduced the policy of blending ethanol with petroleum keeping in view increasing cost of non-renewable petroleum products,. The possible ethanol production from available sugarcane molasses and other sources is 2000 million litres $\mathrm{yr}^{-1}$ against the requirement of ethanol in order to blend with petrol (10\%), diesel (5\%) and other purposes is 5000 million litres $\mathrm{yr}^{-1}$ leaving a deficit of 3000 million I $\mathrm{yr}^{-1}$ of ethanol in India. The present fuel policy has renewed interest in sweet sorghum because it is best suited for ethanol production due to low water requirement, less cost of production, higher total reducing sugars and poor sugar content compared to sugarcane juice (Huligol et al., 2004). With respect to plant nutrition, imbalance application is one of the most important problems facing in agriculture (Regeo et al., 2013). Nitrogen plays a significant role in plant growth and development. Further, most of the farmers are not applying potassium fertilizer with a perception that Indian soils are rich in $\mathrm{K}$ and need no of extraneous application (Tewari, 2006). If total soil $\mathrm{K}$ content is adequate, the release rate in most cases has not been enough to meet crop requirement (Hunsigi, 2001). In the present day intensive and high yield oriented agriculture, there is negative $\mathrm{K}$ balance and consequently, the soils are mined of the essential nutrient (Roy, 2000). The response to $\mathrm{K}$ application is site and crop specific and in many cases, economic as well (Stauffer et al., 1995). Pholsen and Sornsungneon (2000) reported that, increase in $\mathrm{N}$ and $\mathrm{K}_{2} \mathrm{O}$ levels significantly increased most growth parameters of the sorghum crop. The synergistic interaction of $\mathrm{N}$ and $\mathrm{K}$ was well explained by Aulakh and Mahli (2005) in different crops. Although the effect Potassium on growth and yield of other crops reported, but there is a limited reports regarding effect of $\mathrm{K}$ on growth and juice yield of sweet sorghum which has economic value. Therefore the current experiment was carried out to know effect of different $\mathrm{N}$ and $\mathrm{K}$ levels on stalk, juice and grain yield and brix value sweet sorghum cultivars. 


\section{Materials and Methods}

The present study was mainly aimed at quantifying the influence of nitrogen and potassium nutrients on recently developed sweet sorghum cultivars. The trial was conducted for two years during maghi (late kharif) season of 2008-09 and 2009-10 at Agricultural Research Station (ARS), Madhira in Khammam district, Telangana State. The soil of the experimental site was of medium to deep black soil with $8.33 \mathrm{pH}$ (Glass electrode $\mathrm{pH}$ meter by Jackson, 1967), EC was $0.055 \mathrm{dS} \mathrm{m}^{-1}$ (Conductivity bridge method by Jackson, 1967), organic carbon was 0.41 (Walkley and Black's modified method by Jackson, 1967) and available $\mathrm{N}$ was $205 \mathrm{~kg} \mathrm{ha}^{-1}$ (Alkaline permanganate method by Subbaiah and Asija, 1956), available K was $175 \mathrm{~kg} \mathrm{ha}^{-1}$ (Olsen's method by Olsen et al., 1954) and available $P$ was $30.4 \mathrm{~kg} \mathrm{ha}^{-1}$ (Neutral ammonium acetate method Flame Photometer by Jackson, 1967). The experiment included two levels of nitrogen (N) 0 and $80 \mathrm{~kg}$ $\mathrm{ha}^{-1}$ and three levels of potassium (K) 0, 40 and $80 \mathrm{~kg} \mathrm{ha}^{-1}$ as the main plot treatments and sweet sorghum cultivars CSH 22SS and SSV 84 used in 2008 and CSH 22SS and PAC 52093 used in 2009 as sub-plot treatments. It was conducted in a split plot design with three replications. The date of sowing during 2008 was $20^{\text {th }}$ September and during 2009 was $2^{\text {nd }}$ September, while date of harvest was $12^{\text {th }}$ January and $3^{\text {rd }}$ January, during 2008 and 2009 respectively. The crop was raised under rainfed conditions and was managed free from pest and diseases. The gross plot size was $9 \times 6 \mathrm{~m}^{2}$ and net plot size was $7.8 \times 5.6 \mathrm{~m}^{2}$. At harvest, the earhead was separated from the stalk and the total fresh weight was recorded, while the fresh stalk weight was recorded after stripping the leaves. Juice was immediately extracted from the stripped stalk by using sugar cane crushers procured from local cane juice vendors so as to record the brix value using a refractometer and the volume was measured by using a measuring jar. The earheads were threshed, separated and the grain yield was recorded.

\section{Results and Discussion}

The pooled statistical analysis (Table 1) using a split plot design indicated that the yields varied significantly and hence the data was summarized for individual years separately. The results in Table 2 revealed that, application of either $40 \mathrm{~kg}$ or $80 \mathrm{~kg} \mathrm{~K}_{2} \mathrm{O} \mathrm{ha}{ }^{-1}$ alone did not significantly influence biomass, juice yield, brix value and grain yield in sweet sorghum during

\begin{tabular}{lccccc}
\hline \multicolumn{7}{l}{ Table 1: Results of pooled analysis of two years } \\
\hline Pooled & TFY & SFY & GY & JY & BV \\
\hline Years (2008 and 2009) & Sig & Sig & Sig & Sig & Sig \\
$\begin{array}{l}\text { Main plots (Nitrogen and } \\
\text { potassium levels-6) }\end{array}$ & Sig & Sig & Sig & Sig & Sig \\
$\begin{array}{l}\text { Sub plots (Cultivars-2) } \\
\text { Interaction (NK } \times \text { C) }\end{array}$ & NS & NS & Sig & Sig & Sig \\
\hline
\end{tabular}

TFY: Total fresh yield (t ha-1); SFY: Stalk fresh yield (t ha-1); GY: Grain yield (t ha-1); JY: Juice yield $\left(\mathrm{ha}^{-1}\right)$; BV: Brix value (\%); Sig: Significant; NS: Non significant

Table 2: Total plant weight, stripped stalk weight, juice yield, brix value and grain yield response of sweet sorghum cultivars to nitrogen and potassium levels

\begin{tabular}{|c|c|c|c|c|c|c|c|c|c|c|}
\hline \multirow{2}{*}{$\begin{array}{l}\text { Treatments } \\
\text { Years }\end{array}$} & \multicolumn{2}{|c|}{$\begin{array}{c}\text { Total plant weight } \\
\left(\mathrm{t} \mathrm{ha}^{-1}\right)\end{array}$} & \multicolumn{2}{|c|}{$\begin{array}{l}\text { Stripped stalk } \\
\text { weight }\left(\mathrm{t} \mathrm{ha}^{-1}\right)\end{array}$} & \multicolumn{2}{|c|}{$\begin{array}{c}\text { Juice yield } \\
\left(\mathrm{I} \mathrm{ha}^{-1}\right)\end{array}$} & \multicolumn{2}{|c|}{ Brix value } & \multicolumn{2}{|c|}{$\begin{array}{l}\text { Grain yield } \\
\text { (t ha-1) }\end{array}$} \\
\hline & 2008 & 2009 & 2008 & 2009 & 2008 & 2009 & 2008 & 2009 & 2008 & 2009 \\
\hline \multicolumn{11}{|l|}{ Main plots } \\
\hline $\mathrm{N}_{0} \mathrm{~K}_{0}$ & 31.75 & 24.20 & 17.05 & 15.39 & 6549 & 3559 & 13.1 & 12.4 & 3.29 & 2.32 \\
\hline $\mathrm{N}_{0} \mathrm{~K}_{1}$ & 31.08 & 25.32 & 19.52 & 15.85 & 6456 & 3668 & 14.1 & 12.8 & 3.30 & 2.37 \\
\hline $\mathrm{N}_{0} \mathrm{~K} 2$ & 31.60 & 25.10 & 17.89 & 17.63 & 6849 & 3702 & 14.2 & 13.3 & 3.31 & 2.30 \\
\hline $\mathrm{N}_{1} \mathrm{~K}_{0}$ & 33.87 & 33.50 & 22.98 & 21.45 & 7683 & 5117 & 15.5 & 13.9 & 4.36 & 3.08 \\
\hline $\mathrm{N}_{1} \mathrm{~K} 1$ & 40.04 & 35.90 & 25.12 & 23.25 & 8240 & 5665 & 15.6 & 14.0 & 4.46 & 3.22 \\
\hline $\mathrm{N}_{1} \mathrm{~K}_{2}$ & 41.04 & 34.70 & 26.30 & 23.12 & 8353 & 5951 & 15.7 & 14.8 & 4.49 & 3.31 \\
\hline SEm \pm & 0.85 & 1.28 & 0.79 & 1.39 & 254 & 116 & 0.4 & 0.3 & 0.11 & 0.10 \\
\hline$C D(p=0.05)$ & 2.70 & 4.10 & 2.54 & 4.44 & 809 & 369 & 1.4 & 1.0 & 0.34 & 0.31 \\
\hline \multicolumn{11}{|l|}{ Sub plots } \\
\hline CSH 22 SS & 35.04 & 30.96 & 22.40 & 21.38 & 7438 & 5145 & 13.9 & 15.4 & 3.72 & 2.67 \\
\hline SSV 84/ PAC 52093 & 34.75 & 28.62 & 20.56 & 17.52 & 7272 & 4075 & 15.5 & 11.7 & 4.01 & 2.86 \\
\hline SEm \pm & 0.65 & 0.90 & 0.56 & 0.62 & 150 & 127 & 0.3 & 0.2 & 0.06 & 0.07 \\
\hline $\mathrm{CD}(p=0.05)$ & NS & NS & 1.26 & NS & NS & NS & 0.9 & 0.5 & 0.19 & NS \\
\hline
\end{tabular}

CSH 22SS and PAC 52093 were tested during 2008-09; SSV 84 and PAC 52093 during 2009-10 
both years of study. However, a significant improvement in stalk yield, juice yield, brix value and grain yields were observed with nitrogen fertilization @ $80 \mathrm{~N} \mathrm{ha}^{-1}$ alone $\left(\mathrm{N}_{1} \mathrm{~K}_{0}\right)$ when compared to no fertilizer $\left(\mathrm{N}_{0} \mathrm{~K}_{0}\right)$ or application of $\mathrm{K}_{2} \mathrm{O}$ alone either@ $40 \mathrm{~kg} \mathrm{ha}^{-1}\left(\mathrm{~N}_{0} \mathrm{~K}_{1}\right)$ or $80 \mathrm{~kg} \mathrm{ha}^{-1}\left(\mathrm{~N}_{0} \mathrm{~K}_{2}\right)$. The combined effect of $80 \mathrm{~kg} \mathrm{~N}$ and $80 \mathrm{~kg} \mathrm{~K}_{2} \mathrm{O}\left(\mathrm{N}_{1} \mathrm{~K} 2\right)$ was found significant on total and stripped stalk weight and juice and seed yield as compared to that of $\mathrm{N}_{0} \mathrm{~K}_{0}, \mathrm{~N}_{0} \mathrm{~K}_{1}, \mathrm{~N}_{0} \mathrm{~K}_{2}$, however, at par with $\mathrm{N}_{1} \mathrm{~K}_{1}$ ( $80 \mathrm{~kg} \mathrm{~N}$ and $40 \mathrm{~kg} \mathrm{~K}_{2} \mathrm{O} \mathrm{ha}^{-1}$ ) during both the years and $\mathrm{N}_{1} \mathrm{~K}_{0}$ for total plant weight during 2009 and juice yield in 2008 only. Mengal and Kirbay (2001) reported that, corn and sorghum yields increased by 41 and $19 \%$ respectively, with application of $\mathrm{N}$ fertilizer. Pholsen and Sornsungneon (2004) were reported that, combined influence of nitrogenous and potassium fertilizers was significant and positive in increasing most of the growth parameters in sorghum plant. Among the cultivars studied, SSV 84 produced higher mean grain yield of $4.01 \mathrm{t} \mathrm{ha}^{-1}$ in 2008 and PAC 52093 with $2.86 \mathrm{t} \mathrm{ha}^{-1}$ in 2009 over CSH 22SS. But this trend was reverse in terms of total fresh stalk, stripped stalk and juice yields indicating favored partitioning towards the grain. The cultivar CSH 22SS was recorded higher brix value of 15.4 in 2009 which was drought year over its preceding wet year 2008 (13.9) indicating its advantage even during drought year. The linear relationship between fresh stalk yield and juice yield had an $R^{2}$ value of 0.55 (Figure 1). The variation in cultivar response due to interaction effect of $\mathrm{N}$ and $\mathrm{K}_{2} \mathrm{O}$ was not significant. These results are in line with the finding of Buah et al. (2012) who did not observe any significant interactions of fertilizer $\mathrm{N}, \mathrm{P}$, and $\mathrm{K}$ to affect any

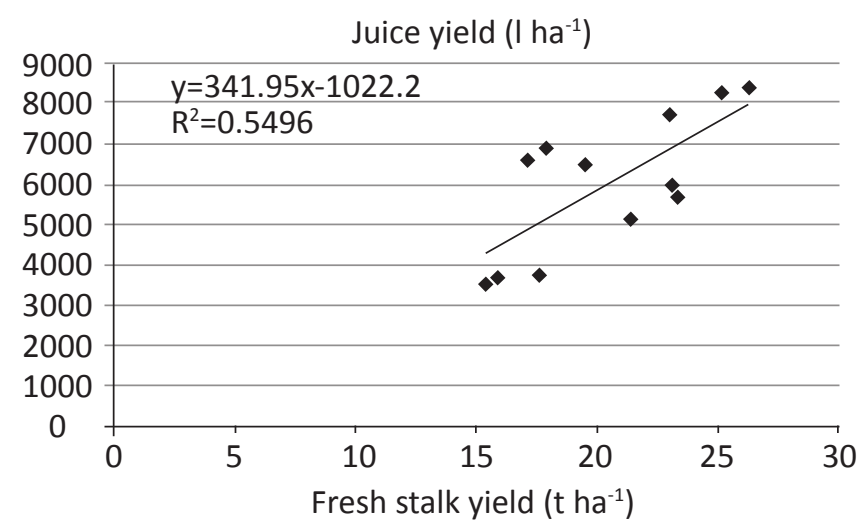

Figure 1: Relationship between fresh stalk yield and juice yield

parameter of sorghum, which might be due to the difference in genotypes used in the two studies. Zia-ul-hassan et al. (2016) concluded that the sorghum genotypes varied widely for their growth and biomass production, however, this variation was independent of their $\mathrm{K}$ accumulation.

The highest net returns of ₹ 47101 and ₹ $32990 \mathrm{ha}^{-1}$ and benefit:cost ratio of 3.37 and 2.37, were recorded with the combined application of $\mathrm{N}$ and $\mathrm{K}_{2} \mathrm{O}$ at their recommended levels of $80 \mathrm{~kg} \mathrm{~N}$ and $\left.40 \mathrm{~kg} \mathrm{~K}_{2} \mathrm{O} \mathrm{ha-1}\left(\mathrm{N}_{1} \mathrm{~K}_{1}\right)\right)$ during 2008-09 and 2009-10, respectively. Among the tested genotypes, the cultivars SSV 84 and PAC 52093 were found superior over CSH $22 \mathrm{SS}$ in terms of net returns and benefit cost ratios during their respective years of study (Table 3).

Table 3: Monetary returns of sweet sorghum as influenced by nutrients and varieties

\begin{tabular}{|c|c|c|c|c|c|c|}
\hline \multirow{2}{*}{$\begin{array}{l}\text { Treat- } \\
\text { ments } \\
\text { Main } \\
\text { plots }\end{array}$} & \multicolumn{2}{|c|}{$\begin{array}{c}\text { Gross returns } \\
\left(₹ h^{-1}\right) \\
\end{array}$} & \multicolumn{2}{|c|}{$\begin{array}{l}\text { Net returns } \\
\left(₹ h^{-1}\right)\end{array}$} & \multicolumn{2}{|c|}{$\begin{array}{l}\mathrm{B}: \mathrm{C} \\
\text { ratio }\end{array}$} \\
\hline & $\begin{array}{c}2008- \\
09\end{array}$ & $\begin{array}{c}2009- \\
10\end{array}$ & $\begin{array}{c}2008- \\
09\end{array}$ & $\begin{array}{c}2009- \\
10\end{array}$ & $\begin{array}{c}2008- \\
09\end{array}$ & $\begin{array}{c}2009- \\
10\end{array}$ \\
\hline $\mathrm{N}_{0} \mathrm{~K}_{0}$ & 45420 & 33170 & 33020 & 20770 & 2.66 & 1.68 \\
\hline $\mathrm{N}_{0} \mathrm{~K}_{1}$ & 45250 & 33980 & 32560 & 21290 & 2.57 & 1.68 \\
\hline $\mathrm{N}_{0} \mathrm{~K} 2$ & 45590 & 33160 & 32610 & 20180 & 2.51 & 1.56 \\
\hline $\mathrm{N}_{1} \mathrm{~K}_{0}$ & 56190 & 44650 & 42540 & 31000 & 3.12 & 2.27 \\
\hline $\mathrm{N}_{1} \mathrm{~K}_{1}$ & 60950 & 46930 & 47010 & 32990 & 3.37 & 2.37 \\
\hline $\mathrm{N}_{1} \mathrm{~K}_{2}$ & 60870 & 47140 & 46640 & 32910 & 3.28 & 2.31 \\
\hline \multicolumn{7}{|l|}{ Sub plots } \\
\hline CSH22SS & 50980 & 39530 & 37665 & 26395 & 2.83 & 1.98 \\
\hline SSV 84/ & 53760 & 40040 & 40445 & 26725 & 3.04 & 2.01 \\
\hline \multicolumn{7}{|l|}{ PAC } \\
\hline 52093 & & & & & & \\
\hline
\end{tabular}

CSH 22SS and PAC 52093 were tested during 2008-09; SSV 84 and PAC 52093 during 2009-10; "The price of fresh stalk ₹ $500 \mathrm{t}^{-1}$ and grain ₹ $9 \mathrm{~kg}^{-1}$

\section{Conclusion}

The combined application of $80 \mathrm{~kg} \mathrm{~N}$ and $40 \mathrm{~kg} \mathrm{~K}_{2} \mathrm{O} \mathrm{ha}^{-1}$ can be recommended for sweet sorghum due to realisation of higher stalk and juice and grain yields besides net returns and $B: C$ ratio. SSV 84 and PAC 52093 were found to be the suitable cultivars for sweet sorghum production.

\section{References}

Aulukh, M.S., Mahli, S.S., 2005. Interaction of nitrogen with other nutrients and water: Effect on crop yield and quality, Nutrientt Use Effeciency, Carbon Seqestration and Environmental pollution. Advances in Agronomy 86, 341-409.

Buah, S.S.J., Kombiok, J.M., Abatania., N., 2012. Grain sorghum response to NPK fertilizer in the Guinea Savanna of Ghana. Journal of Crop Improvement 26(1), 101-115.

Huligol, R.V., Ramakrishna, Govind, M., 2004. A trial with sweet sorghum. CFC and ICRISAT. 2004, 333-337. In: Alternative uses of sorghum and pearl millet in Asia: proceedings of the Expert Meeting, ICRISAT, Andhra Pradesh, India, 1-4 July 2003. CFC Technical Paper No. 34. P.O. Box 74656, 1070 BR Amsterdam, The Netherlands: Common Fund for Commodities; and Patancheru 502 324, Andhra Pradesh, India: International Crops Research Institute for the Semi-Arid 
tropics, 364.

Hunsigi, G., 2001. Sugarcane in Agriculture and industry. Prism Books Pvt. Ltd., Bangalore, 125-38, 207.

Jackson, M.L., 1967. Soil Chemical Analysis. Prentice Hall of India Ltd. New Delhi.

Mengal, K., Kirkby, E.A., 2001. Principles of Plant nutrition: $5^{\text {th }}$ edition. Kluwer Academic Publisher, 605-650.

Olsen, S.R., Cole, V.V., Watanable, E.S., Dean, L.A., 1954. Estimation of Available Phosphorus by extraction with sodium bicarbonate, USDA circular No, 939.

Pholsen, S., Sornsungneon, N., 2004. Effect of nitrogen and potassium rates and planting distance on growth, yield and fodder quality of forage sorghum (sorghum bicolor L. Moench). Pakisthan Journal of Biological Science 7(10), 1793-1800.

Regeo, T.J., Nageswar Rao, V., Seeling, B., Pardhasaradhi, G., Kumar Rao, J.V.D.K., 2013. Nutrient balance a guide to improving sorghum and ground based dryland cropping systems in sem-arid tropical India. Field Crops Research 81(1), 53-68.

Roy, R.N., 2000. Integrated plant nutrient systems-conceptual overview. In: Proceedings of Symposium on "Integrated Plant Nutrient Management", National Fertilizer Development Centre, Islamabad, 45-48.

Ryan, J.G., Spencer, D.C., 2001. Future challenges and opportunities for agricultural R\&D in the semi-arid tropics. Patancheru 502324, Andhra Pradesh, India: International Crops Research Institute for the Semi-Arid Tropics, 83.

Stauffer, M.D., Akhtar, M.E., Saleem, M.T., 1995. Crop response to potassium application. In: Potassium research and development in Pakistan. National Agricultural Research Council (NARC), Islamabad, 53-104.

Subbiah, B.V., Asija, G.L., 1956. A rapid procedure for the determination of available nitrogen in soil. Current Science 25, 259-260.

Tewari, K.N., 2006. Balanced fertilization for agricultural sustainability in Uttar Pradesh. Potash and Phosphate Institute of Canada-India Programme, 133, Sector 23, Gurgaon- (Haryana), I-VI and 1-32.

WBA GBS, 2014. Energy content of bioethanol - 23.4 $\mathrm{MJ} \mathrm{I}^{-1}$. Energy content of biodiesel -35.2 $\mathrm{MJ} \mathrm{I}^{-1}$ in WBA Global Bioenergy Statistics, 1-33.

Zia-ul-hassan, K.K., Oad, Talpur, N., Talpur, K.H., 2016. Biomass partitioning and potassium accumulation of five sorghum genotypes under deficient and adequate potassium nutrition. Pakistan Journal of Agriculture, Agricultural Engineering and Vetarinary Science 32(1), 9-17. 